\title{
Worldwide variations in EGFR somatic mutations: a challenge for personalized medicine
}

\author{
Pierre-Jean Lamy ${ }^{1 *}$ and William Jacot $^{2}$
}

\begin{abstract}
Two studies recently reported around 10\% of EGFR activating mutations in triple negative breast cancers from Asian patients. However, we did not find any EGFR activating mutation in a series of 229 breast tumor samples from European patients. Like in lung cancer, the EGFR mutation profiles seem to be related to the ethnical origin of patients. This is an important point that should be considered when developing anti-EGFR therapies.
\end{abstract}

Keywords: Breast Cancer, EGFR, activating mutations, triple negative, geographic variations

\section{Commentary}

We have read with great interest the study on Epidermal Growth Factor Receptor (EGFR) mutations in breast carcinoma by Ning Lv et al published in Diagnostic Pathology [1]. Since in lung cancer the choice of anti-EGFR therapy is based on the presence of EGFR activating mutations, and due to the importance to the EGFR pathway in breast cancer, it is crucial to evaluate the presence of these mutations in the different subtypes of breast cancer. The authors reported that, in their series of 139 breast cancers, two (1.4\%) tumors harbored activating EGFR mutations in exon 19 and 21 of this gene. One tumor was classified as estrogen receptor (ER) $(1 / 105$, $0.8 \%$ ) positive and the other was a triple negative (TN) tumor $(1 / 10,10 \%)$. Similarly, in a recent study on $70 \mathrm{TN}$ breast cancers, which were previously described to often present an EGFR addiction, Teng et al. found 8 (11.4\%) activating EGFR mutations in exon 19 and 21 [2]. Both works reported findings that were obtained using tumor samples from Asian patients. We recently analyzed a series of $229 \mathrm{TN}$ tumor samples from European patients with primary breast cancer and found that none had activating EGFR mutations [3]. In previous reports concerning smaller series of Caucasians patients, no EGFR activating mutation was found whatever the subtype of breast cancer studied [4-6]. Similarly, in a cohort of 58 Japanese patients, Toyama et al failed to find exon 19

\footnotetext{
* Correspondence: pierre-jean.lamy@montpellier.unicancer.fr 'Laboratoire de Biologie Spécialisée et Oncogénétique, CRLC Val d'AurellePaul Lamarque, 208, rue des Apothicaires, F-34298 France Full list of author information is available at the end of the article
}

and 21 EGFR mutations [7]. These results underline geographic differences in the presence of EGFR activating mutations as it was already described for non-small cell lung cancer [8]. This mutational event, which appears to be mostly limited to Chinese patients with TN breast cancer, could be related to ethnic or environmental factors. However, the question of the origin of the geographical variations in the occurrence of EGFR mutations in lung and breast cancers is unresolved.

Interestingly, a case of breast metastasis from a primary lung cancer that was confirmed by the detection of the same EGFR mutation has been recently reported [9]. This observation confirms that the presence of this mutation is not an obstacle to metastasization/tumor cell growth in the breast microenvironment. Inversely, we should not forget that some breast cancer characteristics, like ER expression and HER2 over-expression, have been also described in lung cancers $[10,11]$. Lung and breast cancer subtypes seem to share some biomarkers and thus could respond to the same therapies.

At the time of personalized medicine in oncology, more than ever, molecular patterns break the limits of classifying tumors according to their localization. Mutation profiles have to be analyzed in sub-groups of specific populations. This is a new and promising challenge for the design of clinical trials involving targeted therapies.

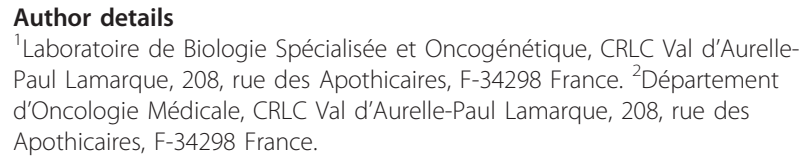




\section{Authors' contributions}

PJL has been involved in drafting the manuscript. WJ has been involved in the critical revision of the manuscript intellectual content. All authors read and approved the final manuscript.

\section{Competing interests}

The authors declare that they have no competing interests.

Received: 3 January 2012 Accepted: 1 February 2012

Published: 1 February 2012

\section{References}

1. Lv N, Xie X, Ge Q, Lin S, Wang X, Kong Y, Shi H, Wei W: Epidermal growth factor receptor in breast carcinoma: association between gene copy number and mutations. Diagn Pathol 2011, 6(1):118.

2. Teng YH, Tan WJ, Thike AA, Cheok PY, Tse GM, Wong NS, Yip GW, Bay BH, Tan PH: Mutations in the epidermal growth factor receptor (EGFR) gene in triple negative breast cancer: possible implications for targeted therapy. Breast Cancer Res 2011, 13(2):R35.

3. Jacot W, Lopez-Crapez E, Thezenas S, Senal R, Fina F, Bibeau F, Romieu G, Lamy P-J: Lack of EGFR activating mutations in European patients with triple negative breast cancer could emphasize geographic and ethnic variations in breast cancer mutation profiles. Breast Cancer Research 2011, 13(6):R133.

4. Bhargava R, Gerald WL, Li AR, Pan Q, Lal P, Ladanyi M, Chen B: EGFR gene amplification in breast cancer: correlation with epidermal growth factor receptor mRNA and protein expression and HER-2 status and absence of EGFR-activating mutations. Mod Pathol 2005, 18(8):1027-1033.

5. Reis-Filho JS, Milanezi F, Carvalho S, Simpson PT, Steele D, Savage K, Lambros MB, Pereira EM, Nesland JM, Lakhani SR, Schmitt FC: Metaplastic breast carcinomas exhibit EGFR, but not HER2, gene amplification and overexpression: immunohistochemical and chromogenic in situ hybridization analysis. Breast Cancer Res 2005, 7(6):R1028-1035.

6. Generali D, Leek R, Fox SB, Moore JW, Taylor C, Chambers P, Harris AL: EGFR mutations in exons 18-21 in sporadic breast cancer. Ann Oncol 2007, 18(1):203-205.

7. Toyama T, Yamashita H, Kondo N, Okuda K, Takahashi S, Sasaki H, Sugiura $H$, Iwase $H$, Fujii $Y$ : Frequently increased epidermal growth factor receptor (EGFR) copy numbers and decreased BRCA1 mRNA expression in Japanese triple-negative breast cancers. BMC Cancer 2008, 8:309.

8. Broet P, Dalmasso C, Tan EH, Alifano M, Zhang S, Wu J, Lee MH, Regnard JF, Lim D, Koong HN, et al: Genomic profiles specific to patient ethnicity in lung adenocarcinoma. Clin Cancer Res 2011, 17(11):3542-3550.

9. Fukumoto K, Usami N, Okasaka T, Kawaguchi K, Okagawa T, Suzuki H, Yokoi K: Late breast metastasis from resected lung cancer diagnosed by epidermal growth factor receptor gene mutation. Lung Cancer 74(2):352-353.

10. Marquez-Garban DC, Mah V, Alavi M, Maresh EL, Chen HW, Bagryanova L, Horvath S, Chia D, Garon E, Goodglick L, Pietras RJ: Progesterone and estrogen receptor expression and activity in human non-small cell lung cancer. Steroids 2011, 76(9):910-920.

11. Liu L, Shao X, Gao W, Bai J, Wang R, Huang P, Yin Y, Liu P, Shu Y: The role of human epidermal growth factor receptor 2 as a prognostic factor in lung cancer: a meta-analysis of published data. J Thorac Oncol 2010, 5(12):1922-1932.

doi:10.1186/1746-1596-7-13

Cite this article as: Lamy and Jacot: Worldwide variations in EGFR somatic mutations: a challenge for personalized medicine. Diagnostic Pathology 2012 7:13.

\section{Submit your next manuscript to BioMed Central and take full advantage of:}

- Convenient online submission

- Thorough peer review

- No space constraints or color figure charges

- Immediate publication on acceptance

- Inclusion in PubMed, CAS, Scopus and Google Scholar

- Research which is freely available for redistribution

Submit your manuscript at www.biomedcentral.com/submit
CioMed Central 